\title{
The effect of anti-inflammatory agents (glucosamine sulphate and aloe vera) on mouse mesenchymal stem cells
}

\begin{abstract}
Use of stem cells for treating degenerative diseases like osteoarthritis has been gaining popularity. Glucosamine Sulphate is a nutritional supplement used for relieving inflammation during Osteoarthritis. Aloe vera juice is a widely consumed drink used in traditional practices to help reduce inflammation. In this experiment, the effect of Glucosamine Sulphate and Aloe vera on 2D and 3D proliferation of MSC cells was studied. Initial study to determine a suitable matrix for growing MSC cells was performed by growing the cells on $5 \mathrm{mg} / \mathrm{ml}$ and $10 \mathrm{mg} / \mathrm{ml}$ collagen and fibronectin coated wells for seven days. Cells adhered the least on fibronectin $10 \mathrm{ug} / \mathrm{ml}$ and cells proliferated the highest on fibronectin at $10 \mathrm{ug} / \mathrm{ml}$, thus establishing fibronectin $10 \mathrm{ug} / \mathrm{ml}$ as the matrix for the study. The effect of Glucosamine Sulphate on 2D proliferation of MSC cells growing on 10ug/ml fibronectin matrix was studied by exposing the cells to $0 \mathrm{mg} / \mathrm{ml}, 0.1 \mathrm{mg} / \mathrm{ml}, 0.5 \mathrm{mg} / \mathrm{ml}$ and $1 \mathrm{mg} / \mathrm{ml}$ of Glucosamine Sulphate for seven days. The cells adhered the least on $0.5 \mathrm{mg} /$ $\mathrm{ml}$ and proliferated the highest on $0.5 \mathrm{mg} / \mathrm{ml}$ as well $(\mathrm{p}<0.05)$. The effect of Aloe vera on MSC cells grown on fibronectin at $10 \mathrm{ug} / \mathrm{ml}$ was studied by using concentrations of $0 \%, 2 \%$, $5 \%$ and $10 \%$ Aloe vera juice for seven days. It was found that cell proliferation radically decreased in all conditions after Day 4 and the least proliferation was observed at 10\%. 3D proliferation of MSC cells in a fibrin construct was studied with $0.1 \mathrm{mg} / \mathrm{ml}$ of Glucosamine Sulphate and $2 \%$ and $5 \%$ Aloe vera juice. It was observed that $5 \%$ Aloe vera juice allowed highest proliferation of cells, followed by $0.1 \mathrm{mg} / \mathrm{ml}$ Glucosamine Sulphate and $2 \%$ Aloe vera. This indicated that further analysis with $2 \%$ and $5 \%$ Aloe vera along with $0.1 \mathrm{mg} / \mathrm{ml}$ as threshold could help identify an optimum dose range for uptake of Glucosamine Sulphate with Aloe vera juice to enhance relief from inflammation during osteoarthritis.
\end{abstract}

Volume 7 Issue I - 2020

\author{
Easwar Kumar Vigneshwari,' Nambiar \\ Roshni,' Sidhu Karandeep,' Tawil Bill, \\ 'Department of Biotechnology and Bioinformatics, California \\ State University, USA \\ ${ }^{2}$ Department of Biomedical Engineering, University of California \\ Los Angeles, USA
}

Correspondence: Bill Tawil, Department of Bioengineering, UCLA School of Engineering, 420 Westwood Plaza, Room 5121, Engineering V. P.O. Box: 951600, Los Angeles, CA 90095-1600, USA, Fax (310) 794-5956,Email bill.tawi@csuci.edu

Received: January 06, 2020 | Published: February 05, 2020

Keywords: glucosamine sulphate, aloe vera, mouse mesenchymal stem cells, antiinflammatory

Abbreviations: msMSC, mouse mesenchymal stem cell;
ECM, extracellular matrix

\section{Introduction}

Osteoarthritis is a degenerative disease of the cartilage in joints affecting over 50 million people in the USA. ${ }^{1}$ Currently a combination of analgesics, Non-Steroidal Anti Inflammatory drugs (NSAIDs), symptomatic slow-acting drugs for OA (SYSDOA), injections of corticosteroids along with adjunctive treatments of food supplements and plant based drugs like curcumin and ginger extracts are used for treatment of OA. ${ }^{2}$ NSAIDs are the major form of treatment for reducing inflammation and pain but are unsuitable for use over extended periods as they have digestive and cardiovascular side effects. ${ }^{3}$ Therefore, SYSDOA such as Glucosamine Sulphate and chondroitin Sulphate are being used for reducing pain and avoiding side effects especially in the elderly population. ${ }^{4}$ Glucosamine Sulphate available as a nutritional supplement is given as a once daily dose of $1500 \mathrm{mg} .{ }^{5}$ Following consumption, $90 \%$ of the supplement is absorbed in the small intestine and only $25 \%$ is bioavailable. Glucosamine (2-amino-2deoxy-d-glucose) is an amino sugar and a major constituent of glycosaminoglycans which helps heal articular damage. ${ }^{6}$ In cartilage it aids formation of proteoglycans hyaluronic acid, heparan Sulphate, keratan Sulphate which are components of ECM of articular cartilage. ${ }^{7}$
Mesenchymal stem cells are adult multipotent cells present in the bone marrow which find applications in regenerative therapies. Regeneration of cartilage in OA with mesenchymal stem cells is currently being investigated. ${ }^{8}$ Induction of differentiation of these cells in a controlled media can cause the growth and development of specific tissue types, for example, growth of MSC on a scaffold with a higher rigidity has been shown to produce osteogenic cells. ${ }^{9}$ This differentiation also depends on the extracellular matrix proteins present in the immediate environment of stem cells that influence their growth and differentiation. Binding of stem cells to ECM proteins such as collagen and fibronectin and subsequent contraction influences their differentiation fate. ${ }^{10}$

Aloe vera is a succulent plant containing biologically active substances that produce anti-inflammatory, immunomodulating and regenerative effects ${ }^{11}$ and has been used for arthritis treatment in the form of oral supplements. ${ }^{12}$ Aloe vera juice is reported to reduce inflammation through the effect of acetylated polysaccharides mannose, acemannan and veracilglucanos B and C. These molecules regulate inflammation by interacting with immune mediators interleukins 6 and $8 .{ }^{13}$ Aloe vera has been widely used in traditional practices to treat wounds and burns but there are no definitive studies that show the beneficial effects of Aloe vera in wound healing. In this study, the effect of Glucosamine Sulphate and Aloe vera juice on MSC cells growing on ECM protein coated wells was studied by 
subjecting the cells to varying concentrations of the agents over seven days. Cell adhesion, cell proliferation was analysed in 2D and 3D in vitro environments.

\section{Materials and methods}

\section{Preparation of stock solutions of glucosamine sulphate and aloe vera}

\section{Glucosamine stock solution preparation}

Proprietary Glucosamine powder was obtained and stock solution of $20 \mathrm{ug} / \mathrm{ml}$ was prepared by dissolving $20 \mathrm{~g}$ of Glucosamine powder in $50 \mathrm{ml} \mathrm{MSC} \mathrm{Basal} \mathrm{media.} \mathrm{For} \mathrm{the} \mathrm{dose} \mathrm{range} \mathrm{study,} \mathrm{in} \mathrm{order} \mathrm{to}$ understand the highest concentration at which the cells cannot tolerate the dose, a dose range from $0 \mathrm{mg} / \mathrm{ml}$ to $20 \mathrm{mg} / \mathrm{ml}$ was conducted confirming a dose below $1 \mathrm{mg} / \mathrm{ml}$ was optimal to further conduct studies. Glucosamine concentrations of $0 \mathrm{mg} / \mathrm{ml}, 0.1 \mathrm{mg} / \mathrm{ml}, 0.5 \mathrm{mg} /$ $\mathrm{ml}$ and $1 \mathrm{mg} / \mathrm{ml}$ was prepared from stock solution and seeded with calculated cell density. 500ul of prepared solution was added to each well ( 3 replicates and 3 blanks per concentration) and plates coated with Fibronectin $10 \mathrm{ug} / \mathrm{ml}$ were incubated at $37^{\circ} \mathrm{C}$. Cell proliferation was determined on Day 1, Day 4 and Day 7 by using calcein treatment method.

\section{Aloe vera juice stock solution preparation}

Aloe Vera juice was purchased from a grocery store. The juice was sterilized by passing through a $0.2 \mu \mathrm{m}$ filter. The gels like particles present in the juice were also removed. The juice was $20 \%$ Aloe Vera juice according to the manufacturers' labeling. Working solutions were prepared keeping in mind the concentration range from $0 \%$ to $10 \%$. The working solutions were prepared to treat the cells seeded on the plates.

\section{MSC culture}

Mouse Mesenchymal Stem Cells were cultured and maintained in MSC Basal Media and DMEM respectively in a $25-\mathrm{ml}$ boat flask at $37^{\circ} \mathrm{C}$.

\section{Cell preparation MSC cells}

Media of msMSC cells growing in T75 flasks was removed and washed with $5 \mathrm{ml}$ sterile PBS to ensure all media has been removed from flask. The cells were treated with $5 \mathrm{ml}$ trypsin in order to detach cells from the bottom of the flask and incubated for around 5-10 minutes. $5 \mathrm{ml}$ of media is added to neutralize trypsin and then transferred into a $15-\mathrm{ml}$ conical tube. The cells are then centrifuged at $200 \mathrm{~g}$ for 5 minutes. The pellet was resuspended in $1 \mathrm{ml}$ of fresh Basal media and 40ul of the cell suspension was added to cellometer slide (20uL per chamber) and analyzed with Nexcelom Cellometer Auto T4 to generate the average live cell concentration.

\section{Coating of wells with collagen and fibronectin}

Calculations were performed in order to ensure 10,000 cells in each well for all wells. Three 24-well plates were coated with Collagen $5 \mathrm{ug} / \mathrm{ml}$, Collagen 10ug/ml, Fibronectin 5ug/ml and Fibronectin 10ug/ $\mathrm{ml}$. Before use, the plates were washed twice with $500 \mathrm{ul}$ of PBS The plates were labeled Day 1, 4, and 7 to ensure proper laboratory procedure

\section{Cell proliferation in 2D}

\section{Plate treatment with Collagen and Fibronectin}

Three 24-well plates were coated with Collagen $5 \mathrm{ug} / \mathrm{ml}$, Collagen 10ug/ml, Fibronectin 5ug/ml and Fibronectin 10ug/ml. Before use, the plates were washed twice with $500 \mathrm{ul}$ of PBS. Calculated number of cells were seeded and plates were incubated at $37^{\circ} \mathrm{C}$.

\section{Calcein treatment of MSC cells}

After incubation of plates, media was removed and cells were washed twice with 500ul of PBS. $200 \mathrm{uL}$ of calcein stain solution was added to each well in the dark and allowed to incubate for 15 minutes. Plates were then analyzed under Filtermax F5 Multi Mode microplate reader to generate fluorescent intensity of live cells. The cells were then viewed under Olympus IX71 fluorescence microscope and images are taken under shatter setting.

\section{Analysis of fluorescence}

Following incubation with Calcein AM, the plates were observed under a fluorescence microscope (Olympus Corporation 1x71). The fluorescence was also quantified in a plate reader (Molecular Devices Filtermax). The readings obtained were made into graphs made in Microsoft Excel.

\section{Cell proliferation in 3D}

$250 \mu \mathrm{L}$ of Thrombin was mixed with $250 \mu \mathrm{L}$ of fibrinogen carefully to ensure formation of construct. The last row of the 24 well plates had no fibrinogen and thrombin. Cells were seeded with an estimate of 10,000 cells for well on the left 12 wells of a 24 well plate. After trypsinizing MSC cells the number of cells obtained were $6.586 \mathrm{x}$ $10 \square$ cells $/ \mathrm{ml}$. In order to obtain 10,000 cells in $500 \mu \mathrm{L}, 15.45 \mu \mathrm{L}$ was added into PBS for Day 1 plate readings. $15.45 \mu \mathrm{L}$ was added into other tubes containing the selected working solutions $(0.1 \mathrm{mg} / \mathrm{ml}$ Glucosamine Sulphate (GS), 2\% Aloe Vera juice and 5\% Aloe Vera) for Day 4 and Day 7 readings. No working solutions were added to Day 1 plate due to the assumption that no significant change would be observed in 1 hour in the presence of working solutions as cells take more than an hour to divide. After the plates were dried with the polymerized 3D fibrin, 500ul of solution containing the cells were added and kept in an incubator at $37^{\circ} \mathrm{C}$.

\section{Results}

\section{Impact of collagen and fibronectin on mouse mesenchymal stem cells}

The fluorescence microscopy images for MSC cells taken over Day 1, Day 3, and Day 7 also show an increase in proliferation over all days for all conditions. For initial cell adhesion for MSC cells, the pattern observed was collagen $5(\mathrm{ug} / \mathrm{ml})>$ collagen $10(\mathrm{ug} / \mathrm{ml})>$ fibronectin $5(\mathrm{ug} / \mathrm{ml})>$ fibronectin $10(\mathrm{ug} / \mathrm{ml})$ with a difference between collagen $10(\mathrm{ug} / \mathrm{ml})$ and fibronectin $10(\mathrm{ug} / \mathrm{ml})(\mathrm{p}<0.05)$. The data was normalized to collagen $5(\mathrm{ug} / \mathrm{ml})$ as $100 \%$. The highest initial adhesion MSC showed highest in collagen $5(\mathrm{ug} / \mathrm{ml})$ at $100 \%$ and the lowest was MSC in fibronectin $10(\mathrm{ug} / \mathrm{ml})$ at $55 \%$.

The cell proliferation patterns in MSC cells were unique as it showed a continuous increase in proliferation in all conditions over all days except for Collagen $5(\mathrm{ug} / \mathrm{ml})$, in which a marginal decrease was observed in Day 7 ( $>0.05)$. MSCs had a higher fold change in fibronectin around 7.5x from Day 1 to Day 7 and a lesser $3.5 x$ increase in collagen Significant differences were recorded in Day 1 vs. Day 4 and Day 1 vs. Day 7 for all conditions. MSC cells showed the highest fold change in fibronectin around 7.5 from Day 1 to Day 7 and 3.5 fold increases in collagen. In proliferation of MSC cells, for Collagen $5(\mathrm{ug} / \mathrm{ml})$, a decrease in Day 7 vs. Day 3 has a standard deviation of $13 \%$ and $12.5 \%$ respectively. 


\section{Impact of glucosamine sulphate at different concentrations on mouse mesenchymal stem cells}

The effects of Glucosamine Sulphate were studied on Day 1 after 1 hour incubation by measuring the initial cell adhesion of MSC cells growing on fibronectin $10 \mathrm{ug} / \mathrm{ml}$ substrate treated with $0 \mathrm{mg} / \mathrm{ml}, 1 \mathrm{mg} /$ $\mathrm{ml}, 10 \mathrm{mg} / \mathrm{ml}$ and $20 \mathrm{mg} / \mathrm{ml}$ Glucosamine Sulphate. $1 \mathrm{mg} / \mathrm{ml}$ showed a fold increase of 0.9 folds when compared to $0 \mathrm{mg} / \mathrm{ml}$ and $10 \mathrm{mg} /$ $\mathrm{ml}$ showed 0.7 fold increase when compared to $0 \mathrm{mg} / \mathrm{ml}(\mathrm{p}<0.05)$. $20 \mathrm{mg} / \mathrm{ml}$ showed a 3.2 fold decrease in adhesion when compared to $0 \mathrm{mg} / \mathrm{ml}(\mathrm{p}<0.05)$ (Figure 2A). In the established dose range of $0 \mathrm{mg} /$ $\mathrm{ml}-1 \mathrm{mg} / \mathrm{ml}, 0.1 \mathrm{mg} / \mathrm{ml}$ showed a 2.2 fold increase in adhesion when compared to $0 \mathrm{mg} / \mathrm{ml}$. $0.5 \mathrm{mg} / \mathrm{ml}$ however, showed a 1.7 fold decrease in comparison to $0 \mathrm{mg} / \mathrm{ml}$. A small increase of 0.9 folds was observed in $1 \mathrm{mg} / \mathrm{ml}$ when compared to control. No significant difference was found (Figure 2C).

Cell proliferation of MSC cells in varying treatments of Glucosamine Sulphate was measured by comparing the number of cells on Day 1, Day 4 and Day 7. Cell proliferation is expressed as percentage of cells as compared to Day 1 . In the dose escalation study, $0 \mathrm{mg} / \mathrm{ml}$ showed the highest proliferation. $1 \mathrm{mg} / \mathrm{ml}$ also showed an increase in proliferation across all days $(\mathrm{p}<0.05) .10 \mathrm{mg} / \mathrm{ml}$ showed a decrease in proliferation from Day 1 to Day 7 as compared to $0 \mathrm{mg} / \mathrm{ml}$ (Figure 2B). $20 \mathrm{mg} / \mathrm{ml}$ also showed a decrease in proliferation across all days as compared to control. This observation established that higher concentrations of $10 \mathrm{mg} / \mathrm{ml}$ and $20 \mathrm{mg} / \mathrm{ml}$ are inhibitory to cell proliferation and thus $0 \mathrm{mg} / \mathrm{ml}-1 \mathrm{mg} / \mathrm{ml}$ was chosen as a suitable dose range for further studies.

Further analysis with newly established dose range was performed with $0 \mathrm{mg} / \mathrm{ml}, 0.1 \mathrm{mg} / \mathrm{ml}, 0.5 \mathrm{mg} / \mathrm{ml}$ and $1 \mathrm{mg} / \mathrm{ml}$ (Figure 2D). An increase in cell proliferation was observed from Day 1 to Day 7 in all treatment conditions. Cell proliferation was the highest in 0mg/ $\mathrm{ml} .0 .1 \mathrm{mg} / \mathrm{ml}, 0.5 \mathrm{mg} / \mathrm{ml}$ and $1 \mathrm{mg} / \mathrm{ml}$ showed a reduced proliferation when compared to $0 \mathrm{mg} / \mathrm{ml}$. $0.5 \mathrm{mg} / \mathrm{ml}$ showed more proliferation than $0.1 \mathrm{mg} / \mathrm{ml}$ and $1 \mathrm{mg} / \mathrm{ml} .1 \mathrm{mg} / \mathrm{ml}$ showed the least proliferation of all the treatments. $0.1 \mathrm{mg} / \mathrm{ml}$ showed a 2.2 fold increase from Day 4 to Day 7 $(\mathrm{p}<0.05) .0 .5 \mathrm{mg} / \mathrm{ml}$ showed highest proliferation ( 2.4 fold increase) from Day 4 to Day $7(\mathrm{p}<0.05)$. Though a decreased proliferation in $1 \mathrm{mg} / \mathrm{ml}$ was observed in comparison to other conditions, a 0.7 fold increase was observed from Day 4 to Day $7(p<0.05)$. The fold increase in $0.5 \mathrm{mg} / \mathrm{ml}$ and $1 \mathrm{mg} / \mathrm{ml}$ when compared to $0 \mathrm{mg} / \mathrm{ml}$ on Day 7 was statistically significant. The results obtained for established concentrations are shown in Figure 2E. Cells are observed to increase from Day 1-Day 7 in all conditions, except $1 \mathrm{mg} / \mathrm{ml}$ in which less number of cells are observed in Day 4 and Day 7 as compared to Day 1.

Impact of Aloe vera at different concentrations on mouse mesenchymal stem cells

The impact of Aloe vera on mouse mesenchymal stem cells was measured through initial cell adhesion and cell proliferation. Initial cell adhesion was found to be the highest for the $0 \%$ Aloe vera relative to $2 \%, 5 \%$ and $10 \%$. No statistical significance was found. Cell proliferation was observed to decline from Day 4 to Day 7 in all conditions except for $10 \%$ Aloe vera (not statistically significant). Overall, a similar trend of decreasing proliferation with increasing concentration of Aloe vera was observed. At $0 \%$ Aloe vera, proliferation increased by 8.8 folds on Day 4 when compared to Day 1 and subsequently reduced by 1.5 folds on Day 7 . At $2 \%$ Aloe vera, proliferation increased by 7.7 folds on Day 4 followed by a decrease of 1.3 folds on Day 7. Similarly, cell proliferation at $5 \%$ Aloe vera increased by 6.9 folds on Day 4 followed by a decrease of 1.2 folds on Day 7. For the highest concentration of $10 \%$, proliferation decreased by 1.6 folds on Day 4 followed by an increase of 1.2 folds on Day 7 , however the fold changes seen at $10 \%$ Aloe vera were not statistically significant.

Among each concentration group of Aloe vera, fluorescence values were significant within the group of each concentration; Day 1 relative to Day 4, Day 4 relative to Day 7. However, at 10\% Aloe vera, Day 1 vs. Day 4 was found to be significant, but Day 1 vs. Day 7 was not significant. The $p$ value was considered to be significant for value less than 0.05 . When comparing Day 1 of $0 \%$ to Day 1 of $2 \%$, $5 \%$ and $10 \%, \mathrm{p}$ was greater than 0.05 . Statistically significant values were observed on Day 4 at $0 \%$ Aloe vera with Day 4 at $10 \%$ Aloe vera, Day 4 at $2 \%$ Aloe vera with Day 4 at $10 \%$ Aloe vera, Day 4 at $5 \%$ Aloe vera with Day 4 at 10\% Aloe vera. At Day 7, 10\% Aloe vera was found to be statistically significant when compared with $0 \%$ Aloe vera on Day 7, 2\% Aloe vera on Day 7 and $5 \%$ Aloe vera on Day 7 . All other comparisons were not found to be statistically significant.

\section{Impact of glucosamine sulphate and aloe vera on mouse mesenchymal stem cells grown in a 3D fibrin construct}

Initial cell adhesion and proliferation were observed in a 3D fibrin construct. Initial cell adhesion was found to be the highest in cells grown two dimensionally. Among the components, cells grown at $2 \%$ Aloe vera was the highest followed by $5 \%$ Aloe vera and Glucosamine Sulphate. Cell proliferation and morphology was observed to change drastically when moving onto 3D from 2D. Cell proliferation showed a similar trend in all conditions in 3D. However, 3D cell proliferation tended to be higher on Day 7 at $5 \%$ Aloe vera. A similar trend was also observed in $3 \mathrm{D}$, where cell proliferation decreased in the presence of Aloe vera verses cells in 2D. For cells grown on a 2D surface, cells grew 13 folds more on Day 4 when compared to Day 1. Cells decreased in growth by 2.6 folds on Day 7 when compared to Day 4. For cells grown on $2 \%$ Aloe vera in $3 \mathrm{D}$, cells grew by 2.6 folds on Day 4 when compared to Day 1 and decreased by 1 fold on Day 7 when compared to Day 4.For 5\% Aloe vera, cells grew by 3.2 folds on Day 4 when compared to Day 1 and interestingly increased by 5 folds on Day 7 when compared to Day 3(not statistically significant). For $0.1 \mathrm{mg} / \mathrm{ml}$ Glucosamine Sulphate, cells grew by 3.4 folds on Day 4 when compared to Day 1 and also increased by 1.3 folds on Day 7 when compared to Day 4.

Among all component groups of cells in 3D and 2\%, fluorescence values were significant within the group of each concentration; Day 1 relative to Day 4, Day 4 relative to Day 7 . However, for 5\% Aloe vera, $p<0.05$ when comparing Day 1 and Day 4 but was not significant for Day 1 compared to Day 7. The $\mathrm{p}$ value was considered to be significant for value less than 0.05 . When comparing Day 7 across each component, $p$ was less than 0.05 for Day 7 of each component in $3 \mathrm{D}$ relative to Day 7 of cells in $2 \mathrm{D}$. Also, $\mathrm{p}<0.05$ for $5 \%$ Aloe vera on Day 7 relative to Day 4 of cells on 2D.

\section{Discussion}

In order to determine the effect of Glucosamine Sulphate and Aloe vera on msMSC cells, adhesion and proliferation of MSC cells was studied. Mesenchymal stem cells are important in the generation of 
bone, cartilage and other tissues. The ability of stem cells to adhere to scaffolds is important for determining their cellular fate. The effect of collagen and fibronectin on mouse mesenchymal stem cells was studied and the results indicate that specific types of matrix media are more optimal for cellular growth at different concentrations. The experiment was designed to show how complex cellular behavior is influenced in the 2D level by different matrix media proteins. Determination of suitable matrix for growing the cells was performed by comparing the cell adhesion and proliferation of the cells grown on Collagen and Fibronectin (Figure 1(A\&B)) over seven days $(\mathrm{N}=3)$. For initial adhesion it was observed that MSC cells adhered most to Collagen 5(ug/ml). In MSC, Collagen for both concentrations showed good adherence. It is known that cells adhere to these proteins by the action of Integrins that recognize and attach to the RGD (arginineglycine-aspartic acid) sequence present in these proteins. ${ }^{14} \mathrm{MSC}$ cells that adhered best to Collagen $5(\mathrm{ug} / \mathrm{ml})$ were the least to proliferate because initial adhesion and proliferation have inverse effects. Cells that adhere most have to spend more energy to detach and replicate. Therefore, highest proliferation for MSC was Fibronectin 10 (ug/ml) and adhesion was lowest

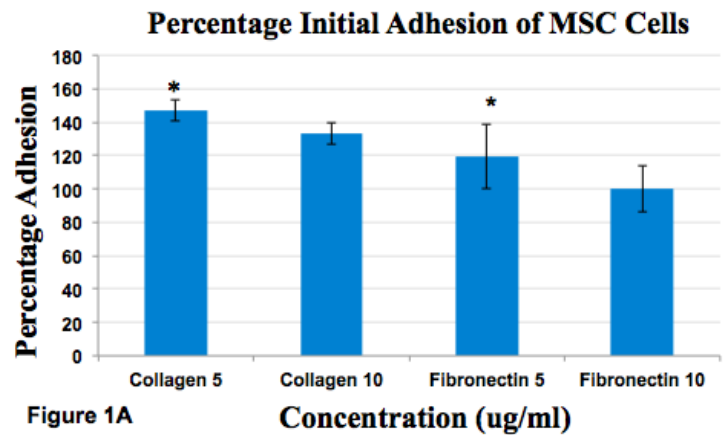

Figure I (A) Effect of Fibronectin and Collagen on msMSC.

Percent Initial Adhesion of MSC Cells. The initial adhesion was calculated for Day I.Initial adhesion was measured by recording number of cells after I hr incubation. Cells adhered $100 \%$ on Fibronectin $10 \mathrm{ug} / \mathrm{ml}$, $147 \%$ on Collagen $5 \mathrm{ug} / \mathrm{ml}$, I33\% on Collagen IOug/ml and I I $9 \%$ on Fibronectin $5 \mathrm{ug} / \mathrm{ml}$. *indicates $\mathrm{p}<0.05$.

\section{Percentage Proliferation of MSC cells}

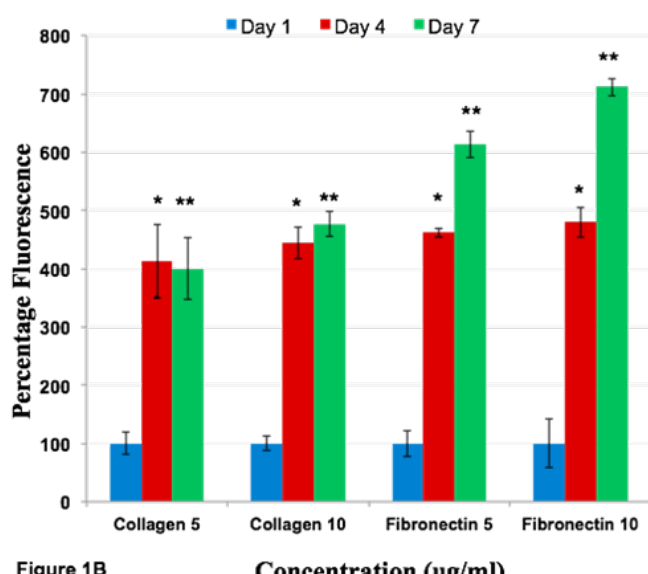

Figure 1B

Concentration (ug/ml)

Figure I (B) Percent Proliferation of MSC Cells.

Proliferation was determined by measuring the number of cells over 7 days. Fold increase of $40 \%$ in Collagen $5,47 \%$ in Collagen 10,61\% in Fibronectin 5 and $71 \%$ in Fibronectin 10 was observed. Proliferation increased on Day 7 in Fibronectin wells, Collagen 10 well and decreased on Day 7 in Collagen 5 wells. * indicates $\mathrm{p}<0.05$ for Day I vs. Day 4 ; ** indicates $\mathrm{p}<0.05$ for Day I vs. Day 7

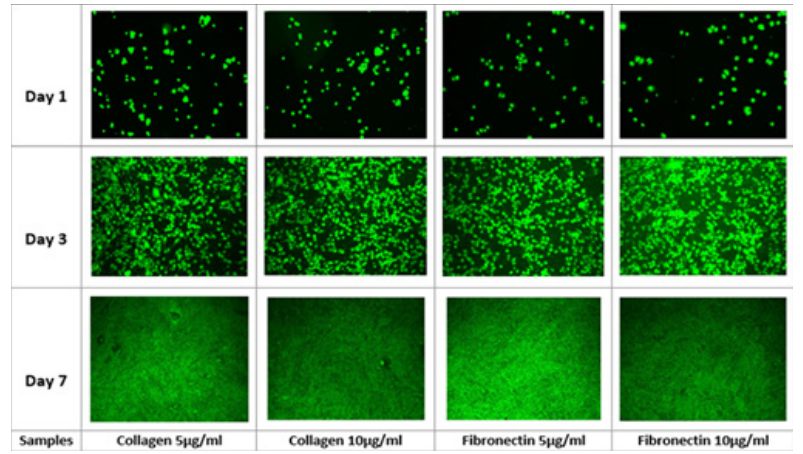

Figure I (C) Fluorescent Imaging of msMSCs Grown On Various Concentrations of Collagen and Fibronectin.

MSC cell types showed increased proliferation in presence of fibronectin when compared to collagen. A possible explanation for this can be the tethering and contraction of fibronectin in the matrix to form fibronectin fibrils which allows actin contraction in the cell and thus contraction of the cells. These contractions of the cells influence its cell fate and thus the control and fabrication of the ECM proteins on scaffolds is important. ${ }^{15}$ It can be concluded that fibronectin is a conductive scaffold to proliferate cells and differentiate them. Cells adhere to these proteins by the actions of integrins that recognize and attach to the RGD. ${ }^{18}$ From the experiment, it can be stated that fibronectin is a conducive scaffold to proliferate and differentiate. It is stated in literature that cells in fibronectin media grow exponentially when given the right conditions and opportunity.$^{16}$ In literature it states that there certain signaling pathways that are turned off and on according the environment fibronectin is surrounded by. ${ }^{17}$ More repetitions of the experiment need to be carried out to determine the optimised range of concentration at which cells grow best. Owing to the less number of repetitions $(\mathrm{N}=3)$, significant conclusions cannot be drawn and thus repetition of the experiments should be performed.

Oral Glucosamine Sulphate is available as an over-the-counter (OTC) nutritional supplement for management of Osteoarthritic pain in the United States. ${ }^{19}$ Glucosamine is an amino sugar involved in the biosynthesis of proteoglycans and glycosaminoglycans which are major components of articular cartilage.$^{20}$ Therefore, it is hypothesized that dietary supplementation of Glucosamine Sulphate could aid in cartilage regeneration by restoring the glycosaminoglycan's and associated proteins. Though the mechanism of action of Glucosamine Sulphate is unclear, an accepted mechanism is reversal of proinflammatory effects of Interleukin-1. In vivo clinical studies evaluating the efficacy of Glucosamine supplements have shown that they are capable of relieving OA symptoms. ${ }^{21}$

In this study, effect of Glucosamine Sulphate on proliferation of MSC cells was studied over 7 days $(\mathrm{N}=9)$. In the dose estimation study, it was found that cell proliferation of MSC cells reduced with an increase in concentration of Glucosamine Sulphate (Figure 2B) where least proliferation was found in $20 \mathrm{mg} / \mathrm{ml}$. The effect of these increasing concentrations is reinforced with the change in morphology of the cells from Day 1 to Day 7 [Figure not included]. Therefore, optimal dose range of $0 \mathrm{mg} / \mathrm{ml}-1 \mathrm{mg} / \mathrm{ml}$ was established and further experiments with new concentrations were performed. It was observed that cells proliferated the most on $0.5 \mathrm{mg} / \mathrm{ml}$ and $0.1 \mathrm{mg} / \mathrm{ml}$ (Figure 2D) when compared to $1 \mathrm{mg} / \mathrm{ml}$ Glucosamine Sulphate $(p<0.05)$. The cells in $1 \mathrm{mg} / \mathrm{ml}$ show elongated needle like shapes in Day 4 and Day 7 (Figure 2E) which are characteristic features of dying cells. ${ }^{22}$ The trends in both the dose escalation and 
established treatment concentrations showed that concentrations higher than $0.5 \mathrm{mg} / \mathrm{ml}$ had inhibitory effects on cell proliferation, which is similar to the reduced proliferation of chondrocyte cells treated with high concentration of Glucosamine Sulphate $(15 \mathrm{mM})$ observed by Varghese et al. ${ }^{21}$ However, it is to be remembered that the concentration of Glucosamine Sulphate used in this study is 1000 times more than its bioavailability of approximately $10 \mathrm{uM}$ in the body after consumption..$^{23}$ Other studies have used similarly high or superphysiological dose ranges and concluded the effect of Glucosamine Sulphate on cells. ${ }^{24}$ Literature however remains divided on the effect of the supplement. Efficiency of Glucosamine Sulphate to improve articular health was recorded in a number of randomized controlled trials ${ }^{26}$ while no effect of Glucosamine on knee joint space narrowing was also reported. ${ }^{27}$ Due to this unreliability of clinical trials results, there arises a need to establish the actual role of the agent. ${ }^{28}$ It is evident from the study that a higher concentration of the supplement has anti-proliferative effects on the cells. However, the results in our in vitro study cannot be extrapolated to account for in vivo cases since the doses involved are unlikely to be achieved in vivo.

\section{Percentage Initial Adhesion} $(\mathrm{N}=3)$

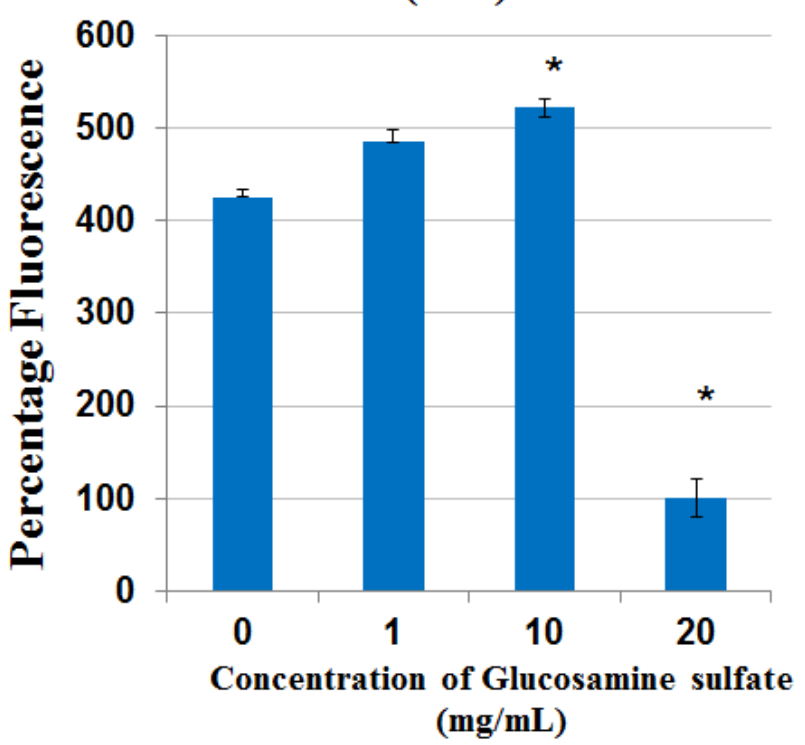

Figure 2 (A) Cell proliferation measured after I hr incubation using calcein staining assay and determining cell proliferation on FilterMax F5 Microplate Reader.

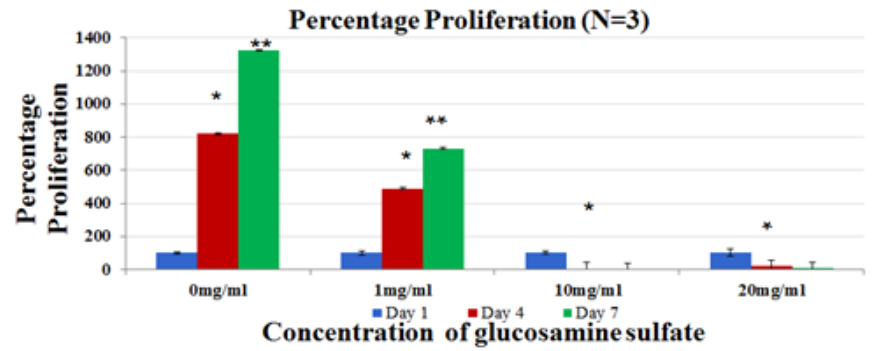

Figure 2 (B) Cell proliferation was measured on Day I, Day 4 and Day 7 using calcein staining assay and data was obtained by reading the plates on FilterMax F5 Microplate Reader.

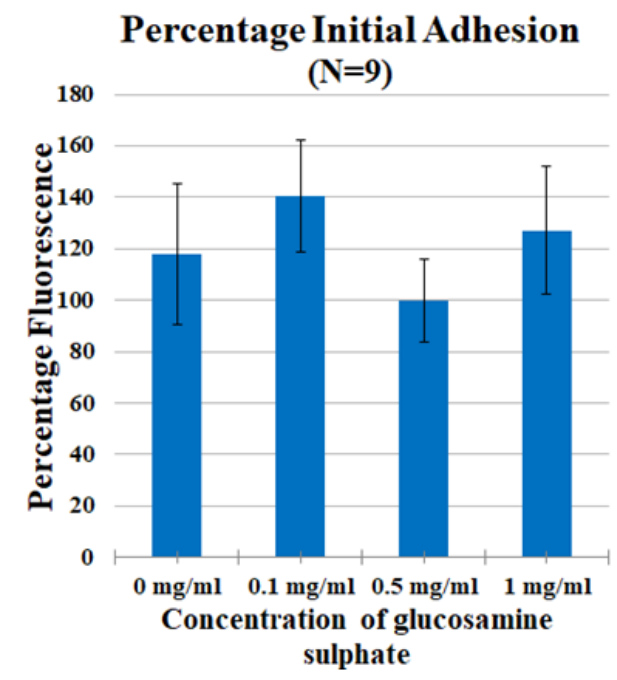

Figure 2 (C) Cell proliferation in $0 \mathrm{mg} / \mathrm{ml}$ - Img/ml Glucosamine Sulphate measured after I hr incubation using calcein staining assay and determining cell proliferation on FilterMax F5 Microplate Reader.

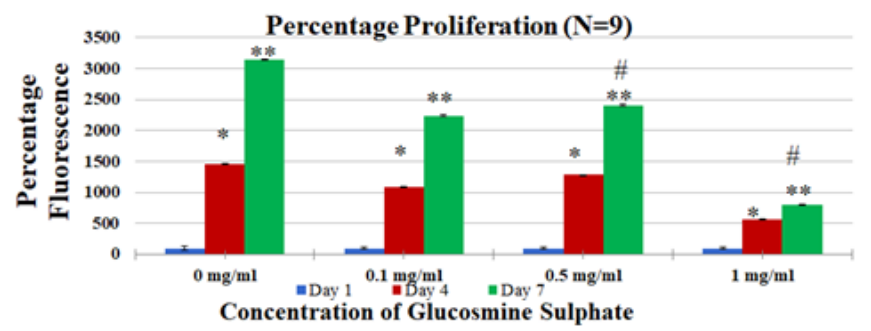

Figure 2 (D) Cell proliferation in $0 \mathrm{mg} / \mathrm{ml}$ - Img/ml Glucosamine Sulphate was measured on Day I, Day 4 and Day 7 using calcein staining assay and data was obtained by reading the plates on FilterMax F5 Microplate Reader.
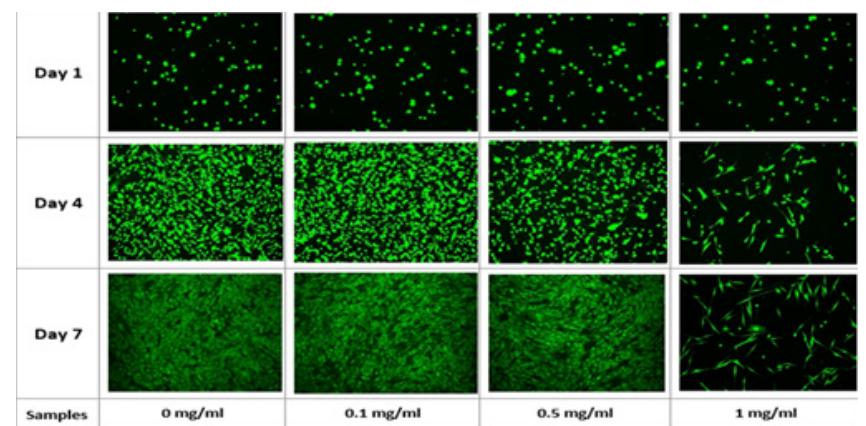

Figure 2 (E) Fluorescent images of MSC cells treated with in $0 \mathrm{mg} / \mathrm{ml}-1 \mathrm{mg} / \mathrm{ml}$ Glucosamine Sulphate taken at I0x magnification using the Olympus $®$ IX7 I fluorescent microscope and $\mathrm{Cy} 3$ filter. The graph is presented as percentage of control where control is untreated cells. The data represent the mean \pm standard deviation (SD) determined by Paired Student T-Test for $\mathrm{N}=3$ where a $P$ value $<0.05$ is considered statistically significant and represented by *.* - $P$ value $<0.05$ for Day I vs. Day 4 , ** - $\mathrm{P}$ value $<0.05$ for Day I vs. Day 7 , \# - P value $<0.05$ Day 7 control vs. Day 7 treatment.

Figure 2 Effect of Glucosamine Sulphate on mouse mesenchymal stem cells.

Aloe vera is a succulent plant found in dry and hot regions. It belongs to the lily family. Aloe Vera has been widely used to treat burns through topical treatment. ${ }^{29}$ Aloe Vera has a very high content of water of about $99-99.9 \%$ with the remaining constituents having 
fungicidal, antimicrobial and immunomodulatory effects. ${ }^{30}$ A study has shown acemannan, one of the components of Aloe Vera leaf to stimulate cell viability of macrophage cell line RAW $264 .{ }^{31}$ Another study reported that oral Aloe Vera gel diluted in 1 in 50 dilutions showed a decrease in prostaglandin E2 production by $30 \%$ as well as a decrease by $20 \%$ for a 1 in 100 dilution. ${ }^{32}$ However, not many studies were conducted on Aloe Vera juice. The antiproliferative effects of Aloe Vera on cancer cells have also been reported in a few studies. ${ }^{34-36}$ A clinical study assessing the effects of Aloe Vera extract administered concomitantly compared to chemotherapy alone on patients suffering from metastatic non-small cell lung cancer showed better partial response rate at $34 \%$ compared to $19 \%$ of patients who received chemotherapy alone. ${ }^{38}$ In this study, Aloe Vera showed reduced cell proliferation of mouse Mesenchymal Stem Cells over increasing Aloe Vera concentrations, however, there was an increase in cell proliferation on Day 7 of $5 \%$ Aloe Vera $(\mathrm{p}<0.05)$ when compared to $0 \%$ Aloe Vera (Figure 3(B\&C)). Decreased cell proliferation over increased Aloe Vera concentrations was also observed (Figure 3(B\&C)). The decreased cell proliferation observed at the concentrations of $2 \%$ and $10 \%$ when compared to the control could be due to dilution in the amount of FBS present in MSC Basal media which occurs when diluting the stock solution of $20 \%$ Aloe Vera to lower concentrations. Initial cell adhesion was also observed to be reduced with increasing Aloe Vera juice concentrations (Figure $3 \mathrm{~A}$ ). Another study using human dental pulp stem cells showed no significant difference between cells treated with $8 \%$ Aloe Vera and the control group, however, the mild inflammation along with increased bone formation was reported. ${ }^{39}$

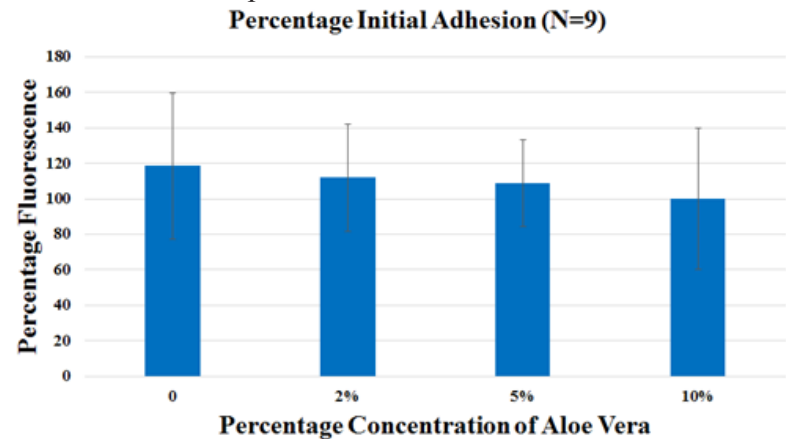

Figure 3 (A) Mouse Mesenchymal Stem cells (msMSC) were seeded on $10 \mathrm{ug} / \mathrm{ml}$ fibronectin and were treated with $0 \%, 2 \%, 5 \%$ and $10 \%$ Aloe Vera juice. Initial cell adhesion was assessed by treating the cells incubated at $37^{\circ} \mathrm{C}$ for I hour, with Calcein AM and reading the fluorescence using the FilterMax F5 Microplate Reader. No statistical significance was observed.

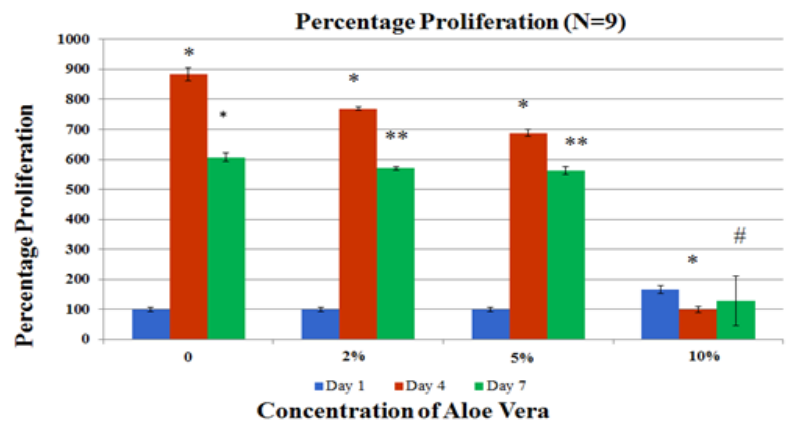

Figure 3 (B) Cell proliferation was assessed by treating cells with Calcein AM and measuring fluorescence with the FilterMax F5 Microplate Reader for time points at Day I, Day 4 and Day 7.

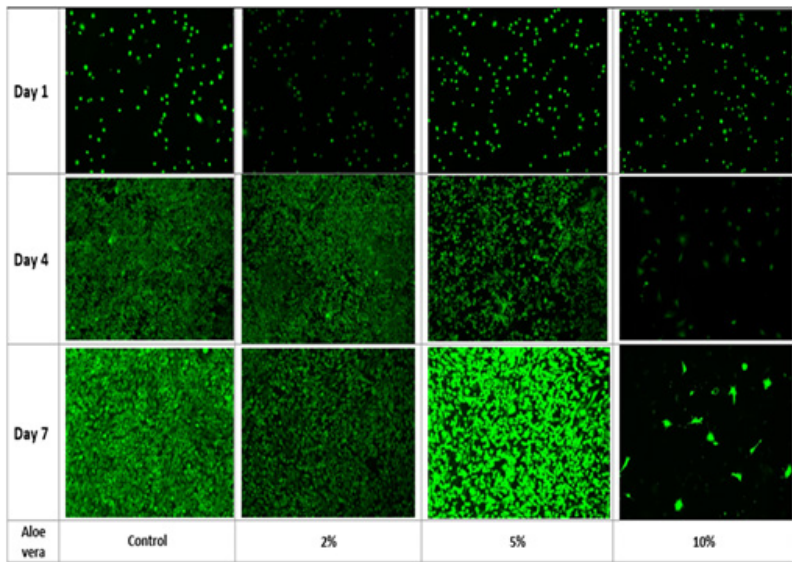

Figure 3 (C) Fluorescent images were taken by treating the cells with Calcein $A M$ and taking fluorescent images using the Olympus ${ }^{\circledR} I X 7 \mid$ fluorescent microscope and Cy3 filter for time points at Day I, Day 4 and Day 7.The data represent the mean \pm standard deviation (SD) determined by Paired Student T-Test for $\mathrm{N}=9$ where a $\mathrm{P}$ value $<0.05$ is considered statistically significant and represented by * for Day I vs. Day 4 for $\mathrm{P}<0.05$, ** for Day I vs. Day 7 for $\mathrm{p}<0.05$ and \# for Day 7 of the $0 \%$ Aloe Vera vs. Day 7 of $10 \%$ Aloe Vera.

Figure 3 Effect of Aloe Vera on mouse mesenchymal stem cells.

Cell culture in 3D has been shown to be different from 2D cell culture in terms of proliferation, differentiation, migration of cells and uptake of nutrients and buildup of waste. ${ }^{40-42}$ Three dimensional culture mimics the natural extracellular environment of a cell than the $2 \mathrm{D}$ cell culture system. Cellular signaling involved in cell proliferation is different when the cells are grown two dimensionally compared to cells grown in a three dimensional system. ${ }^{42}$ The proliferation rates of cells in a 3D system are dependent on the type of cell, the type of ECM in the 3D construct such as a collagen based scaffold or a matrigel based scaffold..$^{42}$ In the case of this study, initial cell adhesion and cell proliferation was slower in the 3D fibrin construct when compared to cells grown two dimensionally (Figure 4(A\&B)). Among the 3D constructs, $2 \%$ Aloe Vera, $5 \%$ Aloe Vera and $0.1 \mathrm{mg} /$ $\mathrm{ml}$ Glucosamine Sulphate were selected. These concentrations were chosen as it was observed in the cell proliferation studies that lower concentrations promoted higher cell proliferation (Figure 2(B\&D)). $2 \%$ Aloe Vera showed the highest cell adhesion (Figure 4A) while cell proliferation was observed to be the highest in 5\% Aloe Vera on Day 7 (not statistically significant). Cell morphology was distinct when comparing the cells grown in $2 \mathrm{D}$ with the cells grown in $3 \mathrm{D}$ fibrin constructs (Figure 4C). This in accordance with literature explaining how the cell signaling can affect the morphology in a 3D system when compared to a $2 \mathrm{D}$ system. ${ }^{42}$

In this study, it was found that proliferation of msMSC cells reduces significantly with high concentrations of Glucosamine Sulphate and Aloe Vera. Therefore, future studies to establish proliferation at lower doses is planned in both $2 \mathrm{D}$ and $3 \mathrm{D}$ proliferation models. Since mesenchymal stem cells in the damaged cartilage differentiate to form chondrocytes which release proteoglycans to rescue the damage, further in vitro studies on differentiation of msMSC cells to chondrocytes is also planned. If found, that msMSC cells supplemented with Glucosamine Sulphate and Aloe vera aid proliferation and differentiation of the cells, performing in vitro and in vivo dosing of a combination of Aloe Vera juice and Glucosamine Sulphate as a mode to relieve inflammation in Osteoarthritis will be the next step. 


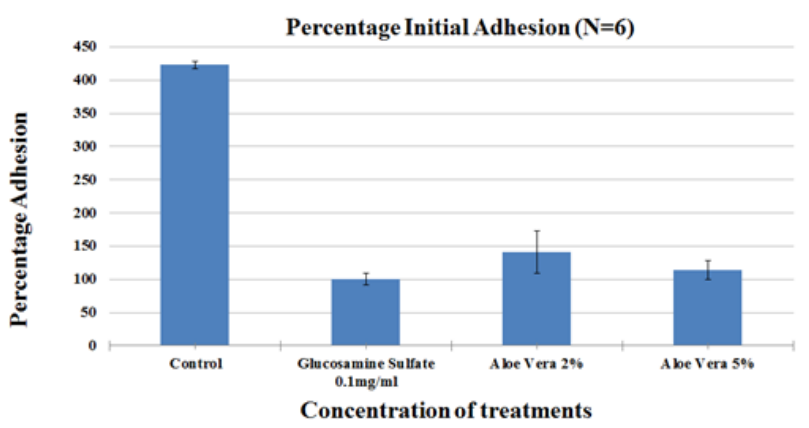

Figure 4 (A) mouse Mesenchymal Stem cells(msMSCs) were seeded in a 3D Fibrin construct and were treated with $2 \%$ Aloe Vera, $5 \%$ Aloe Vera and $0.1 \mathrm{mg} / \mathrm{ml}$ Glucosamine Sulphate. Cells alone were also seeded on $10 \mathrm{ug} / \mathrm{ml}$ fibronectin for $2 \mathrm{D}$ cell growth. Initial cell adhesion was assessed by treating the cells incubated at $37{ }^{\circ} \mathrm{C}$ for I hour, with Calcein AM and reading the fluorescence using the FilterMax F5 Microplate Reader. No statistical significance was observed.

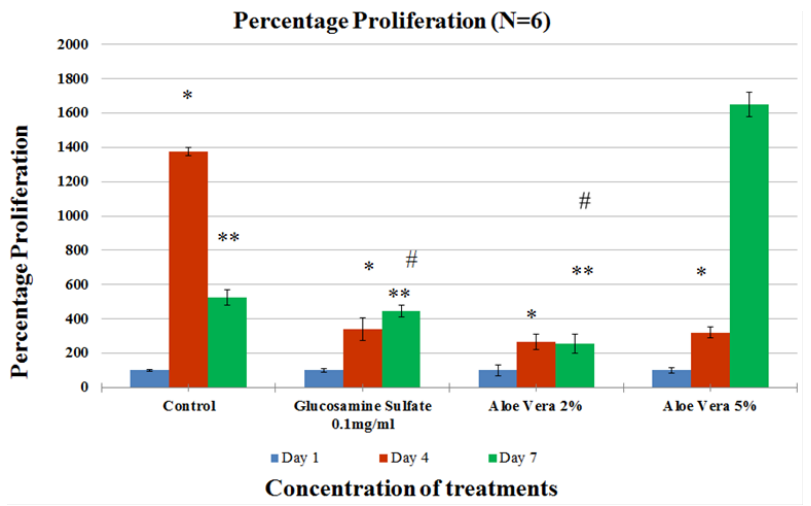

Figure 4 (B) Cell proliferation was assessed by treating cells with Calcein AM and measuring fluorescence with the FilterMax F5 Microplate Reader for time points at Day I, Day 4 and Day 7.

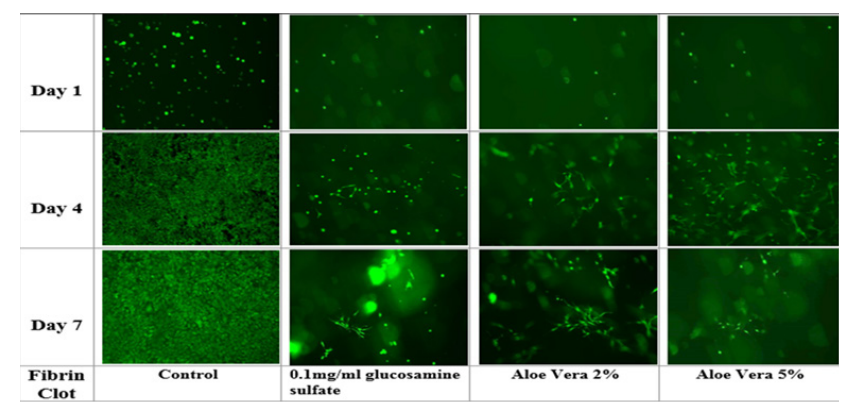

Figure 4 (C) Fluorescent images were taken by treating the cells with Calcein $A M$ and taking fluorescent images using the Olympus ${ }^{\circledR}|X 7|$ fluorescent microscope and Cy3 filter for time points at Day I, Day 4 and Day 7.The data represent the mean \pm standard deviation (SD) determined by Paired Student T-Test for $N=6$ where a $P$ value $<0.05$ is considered statistically significant and represented by * for Day I vs. Day 4 for $\mathrm{p}<0.05$, ** for Day I vs. Day 7 for $p<0.05$ and \# for Day 7 of $2 \%$ Aloe Vera in 3D vs. Day 7 of $0.1 \mathrm{mg} / \mathrm{ml}$ Glucosamine Sulphate in 3D.

Figure 4 Effect of Glucosamine Sulphate and AloeVera on mouse mesenchymal stem cells grown in a 3D fibrin construct.

\section{Acknowledgements}

The authors would like to thank the Melissa McCoy for supporting the group through the experiments and encouraging the research.

\section{Conflicts of interest}

Authors declare that there is no conflict of interest.

\section{Funding}

California State University Channel Islands: Extended University. Department of Biotechnology, Biomedical Engineering Emphasis. One University Drive, Camarillo, California 93012.

\section{References}

1. Barbour KE, Helmick CG, Boring M, et al. Vital Signs: Prevalence of Doctor-Diagnosed Arthritis and Arthritis-Attributable Activity Limitation - United States, 2013-2015. MMWR Morb Mortal Wkly Rep. 2017;66(9):246-253.

2. Conrozier T, Renevier JL, Parisaux JM, et al. Predictive factors of adherence to an association of Glucosamine Sulphate, copper, and ginger extracts in patients with symptomatic osteoarthritis: a prospective open-label French noninterventional study (the PREDOA study). Patient Prefer Adherence. 2019;13:915-921.

3. Bruyère $\mathrm{O}$, Cooper $\mathrm{C}$, Pelletier JP, et al. An algorithm recommendation for the management of knee osteoarthritis in Europe and internationally: a report from a task force of the European Society for Clinical and Economic Aspects of Osteoporosis and Osteoarthritis (ESCEO). Semin Arthritis Rheum. 2014;44(3):253-263.

4. Dougados M. Symptomatic slow acting drugs for osteoarthritis: what are the facts. Joint Bone Spine. 2009;73:606-609.

5. Altman RD. Glucosamine therapy for knee osteoarthritis: pharmacokinetic considerations. Expert Rev Clin Pharmacol. 2009;2(4):359-371.

6. Ramesh C Gupta. Nutraceuticals in Arthritis. Nutracenticals Pages. 2016. p. 365-381.

7. Jerosch J. Effects of Glucosamine and Chondroitin Sulphate on Cartilage Metabolism in OA: Outlook on Other Nutrient Partners Especially Omega-3 Fatty Acids. Int J Rheumatol. 2011;969012.

8. Khalifeh Soltani S, Forogh B, Ahmadbeigi N, et al. Safety and efficacy of allogenic placental mesenchymal stem cells for treating knee osteoarthritis: a pilot study. Cytotherapy. 2019;21(1):54-63.

9. Engler AJ, Sen S, Sweeney HL, et al. Matrix elasticity directs stem cell lineage specification. Cell. 2006;126(4):677-689.

10. Frederick Grinnell. Fibroblast-collagen-matrix contraction: growth-factor signalling and mechanical loading. Trends Cell Biol. 2000;10(9)362-365.

11. Bhat G, Kudva P, Dodwad V. Aloe vera: Nature's soothing healer to periodontal disease. J Indian Soc Periodontol. 2011;15(3):205-209.

12. Yoo EA, Kim SD, Lee WM, et al. Evaluation of antioxidant, antinociceptive, and anti-inflammatory activities of ethanol extracts from Aloe saponaria Haw. Phytother Res. 2008;22(10):1389-1395.

13. Devaraj A, Karpagam T. Evaluation of anti-inflammatory activity and analgesic effect of Aloe vera leaf extract in rats. Int Res J Pharm. 2011;2(3):103-110.

14. Humphries MJ, Travis MA, Clark K, et al. Mechanisms of integration of cells and extracellular matrices by integrins. Biochem Soc Trans. 2004;32:822-825.

15. Kasten A, Naser T, BrüllhoffK, et al. Guidance of mesenchymal stem cells on fibronectin structured hydrogel films. PloS one. 2014;9(10):e109411.

16. Isakson M, de Blacam C, Whelan D, et al. Mesenchymal Stem Cells and Cutaneous Wound Healing: Current Evidence and Future Potential. Stem Cells Int. 2015:831095. 
17. Bill Tawil, Eckhart Kyle, Vaghasia Nikita, et al. The Effect of Soft Drink on Proliferation, Cell Cycle Analysis, and Integrin Expression of Human Foreskin Fibroblast. J Appl Biotechnol Bioeng. 2018;7(4):206-214.

18. Henrotin Y, Mobasheri A, Marty M. Is there any scientific evidence for the use of Glucosamine in the management of human osteoarthritis? Arthritis Res Ther. 2012;14(1):201.

19. Lim ZY, Hussain SM, Cicuttini FM, et al. Bioactive Food as Dietary Interventions for Arthritis and Related Inflammatory Diseases. 2nd ed. Academic Press; 2019. p. 97-137.

20. Sandy JD, Gamett D, Thompson V, et al. Chondrocyte-mediated catabolism of aggrecan: aggreganase-dependent cleavage induced by interleukin-1 or retinoic acid can be inhibited by Glucosamine. Biochem J. 1998;335:59-66.

21. Varghese S, Theprungsirikul P, Sahani S, et al. Glucosamine modulates chondrocyte proliferation, matrix synthesis, and gene expression. Osteoarthritis Cartilage. 2007;15:59-68.

22. Rovati LC, Girolami F, Persiani S. Crystalline Glucosamine Sulphate in the management of knee osteoarthritis: efficacy, safety, and pharmacokinetic properties. Ther Adv Musculoskelet Dis. 2012;4(3):167-180.

23. Piperno M, Reboul P, Hellio Le Graverand MP, et al. Glucosamine Sulphate modulates dysregulated activities of human osteoarthritic chondrocytes in vitro. Osteoarthritis Cartilage. 2000;8:207-212.

24. Largo R, Alvarez-Soria MA, Diez-Ortego I, et al. Glucosamine inhibits IL-1beta-induced NFkappaB activation in human osteoarthritic chondrocytes. Osteoarthritis Cartilage. 2003;1:290-298.

25. Richy F, Bruyere O, Ethgen O, et al. Structural and symptomatic efficacy of Glucosamine and chondroitin in knee osteoarthritis: a comprehensive meta-analysis. Arch Intern Med. 2003;163:1514-1522.

26. Wandel S, Jüni P, Tendal B, et al. Effects of Glucosamine, chondroitin or placebo in patients with osteoarthritis of hip or knee: network metaanalysis. BMJ. 2010;341:c4675.

27. McCarty MF, O'Keefe JH, DiNicolantonio JJ. Glucosamine for the Treatment of Osteoarthritis: The Time Has Come for Higher-Dose Trials. J Diet Suppl. 2019;16(2):179-192.

28. Grindlay D, Reynolds T. The Aloe vera phenomenon: a review of the properties and modern uses of leaf parenchyma gel. J Ethnopharmacol. 1986;16:117-151.
29. Guo X, Mei N. Aloe vera: A review of toxicity and adverse clinical effects. Journal of environmental science and health. Part C, Environmental carcinogenesis \& ecotoxicology reviews. 2016;34(2):77-96.

30. Zhang L, Tizard IR. Activation of a mouse macrophage cell line by acemannan: The major carbohydrate fraction from Aloe vera gel. Immunopharmacology. 1996;35(2):119-128.

31. Langmead L, Makins RJ, Rampton DS. Anti-inflammatory effects of Aloe vera gel in human colorectal mucosa in vitro. Alimentary Pharmacology and Therapeutics. 2004;19(5):521-527.

32. Mishra S, Hull KM, Orleans RJ. Quinacrine Hydrochloride. 2016

33. Tomasin R, Gomes-Marcondes MC. Oral administration of Aloe vera and honey reduces walker tumour growth by decreasing cell proliferation and increasing apoptosis in tumour tissue. Phytother Res. 2011;25(4):619-623.

34. Huang PH, Huang CY, Chen MC, et al. Emodin and Aloe-Emodin Suppress Breast Cancer Cell Proliferation through ER $\alpha$ Inhibition. Evidence-Based Complementary and Alternative Medicine:ECAM. $2013 ; 376123$.

35. Yonehara A, Tanaka Y, Kulkeaw K, et al. Aloe vera Extract Suppresses Proliferation of Neuroblastoma Cells In Vitro. Anticancer Res. 2015;35(8):4479-4485.

36. Aloe Vera. 2018.

37. Lissoni P, Rovelli F, Brivio F, et al. A randomized study of chemotherapy versus biochemotherapy with chemotherapy plus Aloe arborescens in patients with metastatic cancer. In Vivo (Athens, Greece). 2009;23(1):171-175.

38. Soares I, Fernandes G, Larissa Cordeiro C, et al. The influence of Aloe vera with mesenchymal stem cells from dental pulp on bone regeneration: characterization and treatment of non-critical defects of the tibia in rats. Journal of applied oral science: Revista FOB. 2019;27:e20180103.

39. Duval K, Grover H, Han LH, et al. Modeling Physiological Events in 2D vs. 3D Cell Culture. Physiology (Bethesda, Md.). 2017;32(4):266-277.

40. Bonnier F, Keating ME, Wróbel TP, et al. Cell viability assessment using the Alamar blue assay: A comparison of 2D and 3D cell culture models. Toxicology in Vitro. 2015;29(1):124-131.

41. Baker BM, Chen CS. Deconstructing the third dimension: how 3D culture microenvironments alter cellular cues. Journal of cell science. 2012;125(Pt 13):3015-3024. 